DOI:10.31696/2072-8271-2020-2-2-47-075-085

\title{
Covid-19 в Таиланде и борьба с его последствиями
}

\section{Фомичева Елена Алексеевна}

кандидат исторических наук, старший научный сотрудник Центра ЮгоВосточной Азии, Австралии и Океании ИВ РАН, Россия, Москва, elen-fomicheva@yandex.ru, https://orcid.org/0000-0001-8998-4058

Аннотация: Автор представляет картину распространения коронавируса в Таиланде по времени и по территориям. Дает характеристику особенностей его развития и ставит вопрос о причинах достаточно легкого течения пандемии в Таиланде. Действия властей по борьбе с заболеваемостью вирусом оцениваются как вполне удовлетворительные. Приводятся оценки возможных потерь в экономике страны, переживающей спад темпов роста, особенно в туристической отрасли, что осложняется небывалой засухой. В статье также рассматриваются стратегические направления политики по преодолению нынешних негативных явлений в экономике.

Ключевые слова: Таиланд, Ковид-19, проблемы экономики

\section{Covid-19 in Thailand and Dealing with its Consequences}

\section{Elena A. Fomicheva}

$\mathrm{PhD}$ in History, Senior Researcher at the Center for Southeast Asia, Australia and Oceania Studies, Institute of Oriental Studies RAS, Russia, Moscow, elen-fomicheva@yandex.ru, https://orcid.org/0000-0001-8998-4058

Abstract: The author presents a picture of the spread of coronavirus in Thailand by time and territory. It characterizes the features of its development and raises the question of the causes of a fairly easy course of the pandemic in Thailand. The actions of the authorities to combat the incidence of the virus are assessed as quite satisfactory. Estimates of possible losses in the economy of a country experiencing a slowdown in growth rates, which is complicated by an unprecedented drought and pandemic, especially in the tourism industry, are given. The article also discusses strategic policy directions to overcome the current negative phenomena in the economy.

Keywords: Thailand, Covid-19, economic problems

(C) Фомичева Е.А., 2020 
Распространение по времени, количеству и регионам. Впервые о появлении в стране случая заражения COVID-19 было заявлено 13 января. Заболевание было привнесено приехавшими из Китая, из г. Ухань в Бангкок и Чиангмай. Распространение заболевания из Китая представляло для Таиланда особую опасность ввиду огромного количества китайских туристов, посещающих страну. Наиболее популярны среди китайских туристов Бангкок, Чиангмай, Чианграй, Чонбури, Краби, Пхукет, Прачуапкирикан и Самутпракан. На ситуацию в этих районах правительство Таиланда обращало особое внимание. Однако среди туристов или вернувшихся в январе из-за рубежа таиландских граждан заболевших было немного. 31 января зафиксирован первый случай передачи вируса внутри страны. К концу февраля сообщалось о 40 случаях. Резкое увеличение числа инфицированных произошло в марте, что связывали с массовым посещением стадиона тайского бокса 6 марта. На протяжении недели рост составлял по 100 чел. в день. В марте после вспышки численности заболевших решением премьер-министра Праюта Чаноча были закрыты места скопления народа (торговые центры и т.д.), отменены массовые мероприятия, включая Сонкран - обычно многолюдный праздник, во время которого жители обливают друг друга водой, и который проводится в апреле. Объявлено чрезвычайное положение (вступило в силу с 26 марта), а с 3 апреля введен комендантский час в столице и в ряде провинций. С 4 апреля приостановлены все зарубежные авиарейсы. В аэропортах Таиланда был введен запрет на прибытие международных авиарейсов, кроме ряда строго оговоренных случаев. Этот режим был продлен до 30 июня. Исключение сделано лишь для дипломатов, держателей рабочей визы при условии соблюдения 14-дневного карантина по прибытии ${ }^{1}$.

В апреле число новых случаев пошло на убыль. В середине мая число заболевших от контактов внутри страны сократилось до нуля. Постепенно ограничения стали сниматься. 12 июня объявлено о начале четвертого этапа снятия ограничений с 15 июня. Полностью отменен комендантский час с 23:00 до 03:00². Открываются все частные школы, детские сады, ясли и профтехучилища с количеством учеников не более 100 человек. Разрешены краткосрочные мероприятия по повышению квалификации сотрудников, а также продажа алкогольных напитков. Режим чрезвычайного положения был отменен, но, как оказалось, эта мера была временной. Почти одновременно с отменой ЧП правительство намекнуло о возможно- 
сти уже в третий раз продлить его действие ${ }^{3}$, мотивируя это тем, что пандемия в мире не закончилась и что Таиланд переживает кризис, а экономика находится в тяжелом состоянии. В итоге ЧП было продлено уже в третий раз, причем оно предусматривает запрет на массовые политические акции и дает правительству особые полномочия для их подавления. Для «сохранения безопасности страны, как сказал премьер-министр Прают Чан-оча, не следует раздувать конфликты» ${ }^{4}$. Очевидно, что сохранение чрезвычайного положения - мера политическая. Поэтому она вызывает критику в политических кругах.

Действия правительства. В своих действиях правительство опиралось на рекомендации ВО3 и таиландского Департамента контроля за заболеваниями по модели трех ступеней: измерение температуры и отслеживание симптомов в аэропортах и в больницах, обследование мест активизации вируса, гигиена и наблюдение в образовательных учреждениях, ношение масок и недопущение скопления народа. Гражданам, вернувшимся из стран с высоким риском заболевания, предлагалось соблюдать карантин. С 5 марта прибывшие из-за границы стали помещаться в обсервацию. С 19 марта для прибывших иностранцев требуется медицинская справка и страховка. Как и в других странах на начальном этапе правительство подвергалось критике за нехватку медицинских масок и слабые меры по пресечению спекуляции ими, нерешительность и медлительность в принятии мер, недостаточность информирования граждан. В Бангкоке медицинские маски продавали по 70 бат за штуку, то есть в 70 раз дороже, чем до пандемии. Правительство быстро поставило распространение необходимых медицинскогигиенических средств под контроль. 4 февраля специальным указом 4 вида товаров, включая медицинские маски, полипропилен, спиртосодержащие санитайзеры для рук и туалетную бумагу были включены в число товаров, подлежащих государственному контролю за ценами в соответствии с законом. В случае нарушения закона предусмотрена юридическая ответственность. Таким образом, правительство отрегулировало вопрос с доступностью медицинских масок и дезинфицирующих средств, а также пресекло спекуляции. Чтобы оперативно решать возникающие проблемы был создан Центр управления ситуацией с COVID-19. C 1 июля началась 5 фаза выхода из режима ограничений. В целом, следует признать эффективность организационно-административных и санитарно-гигиенических мероприятий, проводимых правительством Таиланда. 
Медицина. По данным на 16 июня в Таиланде было зарегистрировано 3135 случаев заражения COVID-19, из них 244 - заразились внутри страны, 198 человек находились на карантине 5 Большинство заболевших в возрасте 20-39 лет, то есть в работоспособном возрасте. Много бессимптомных случаев. Общее число смертей от коронавирусной инфекции в Таиланде составляло 58 человек. В активной фазе болезни находились 90 человек, из них 1 в критическом состоянии. Уровень летальности - 1,85\%. Подтвержденных случаев полного излечения от вируса 2987. На 17 июня в Таиланде на протяжении 23 дней не было передачи вируса внутри страны. Устойчивым периодом, свободным от инфекции ученые считают 28 дней. Однако уже после этого периода имеют место единичные заболевания. Поэтому жителей просят соблюдать масочный режим. Поскольку, по словам чиновников, все случаи - завозные, правительство держит под контролем 64 граждан Таиланда, находящихся в Ухани. На 1 июля цифры таковы: всего случаев заболевания 3 173, выздоровели 3 059, новых случаев 2, умерли 58. Таиланд находится на 95 месте в мире по числу заболевших 6 .

Незначительное число заболевших в Таиланде пока не объяснено. Делаются попытки ссылаться на различные факторы: жаркая погода, развитая медицинская инфраструктура. Живущие в стране иностранцы говорят о повсеместной доступности медицинских масок, перчаток, дезинфицирующих гелей. Они подчеркивают дисциплинированность тайцев, которые не нарушают введенных запретов (включая запрет на празднование Сонкрана, любимого праздника тайского Нового года в апреле). Лечение от коронавируса для граждан Таиланда бесплатное, для иностранцев - за деньги. Министр здравоохранения Таиланда заявил об эффективности лечения коронавируса сочетанием препарата против СПИДа «Лопинавир /Ритонавир» и лекарства от гриппа «Осельтамивир», которое применялось для лечения ближневосточного респираторного синдрома (MERS). Информация об этом появилась 3 февраля 2020 в РИА Новости. Однако это сочетание лекарств применялось в единичных случаях, и требует проведения исследований.

Экономика. Пандемия нанесла серьезный ущерб экономике страны, замедлив ее рост, уменьшив поступления в бюджет. Все это наложилось на уже имевшее место снижение темпов роста экономики страны, которое наблюдалось на протяжении нескольких лет, и небывалую засуху. Эпидемия вызвала безработицу, ухудшила материальное положение многих граждан. Она сократила внутренний 
рынок, привела к банкротству и закрытию большого числа предприятий среднего и мелкого бизнеса. Международный валютный фонд прогнозировал падение темпов роста экономики Таиланда на 6,7\% по сравнению с более ранним (до пандемии) прогнозом в 2,5\%. В свою очередь Банк Таиланда в конце июня предсказывал еще более резкое сокращение темпов роста на 8,1\% в текущем 2020 г. а это хуже, чем прогноз того же Банка Таиланда, сделанный в марте и составлявший падение темпов роста на 5,3\%. В таиландском правительстве, экспертном сообществе, в прессе, обществе обсуждаются возможные краткосрочные и среднесрочные стратегии решения проблем экономики по окончании пандемии, которая совпала с небывалой засухой, самой тяжелой за 40 лет. Одна только борьба с последствиями засухи составит, по оценкам Крунгси банк, 46 млрд бат ${ }^{7}$.

Если говорить о текущей деятельности правительства Таиланда в условиях пандемии коронавируса, то, как и в других странах, власти прибегли к мерам прямой помощи пострадавшим, а также к стимулированию восстановления рабочих мест, включая денежную помощь в 1,9 трлн бат. Видимо, следуя общим мировым рекомендациям, правительство стремилось своими методами финансовой поддержки не допустить массового сокращения работников и роста безработицы.

Удивительно, что уже в январе, когда еще не было объявлено о пандемии, международные организации публиковали прогнозы о его экономических последствиях в разных странах, включая Таиланд, а также о путях их преодоления. Правительством страны в январе был разработан план восстановления экономики после пандемии. Одновременно ведется работа над масштабным планом вывода экономики из кризиса на путь устойчивого развития стоимостью 400 млрд бат. В частности, он должен был предусмотреть помощь разного рода (самопомощь, переподготовку, предоставление начального капитала и т.д.) гражданам, включая 24 млн неофициальных работников (10 млн из них - сельскохозяйственные рабочие ${ }^{8}$. Эту категорию работников МОТ включила как одну из 5 групп уязвимых работающих граждан. Неофициальные работники содержат семьи из 4-5 человек, и тратят на это до 60\% заработка. В период пандемии коронавируса они потеряли 80-96\% заработка. Из-за увольнений во время кризиса ряды неофициальных работников пополнились. К тому же они обременены долгами. Правительство выделяет им во время пандемии определенную материальную 
помощь, которую можно рассматривать лишь как кризисную поддержку, которая, однако, не решает кардинально проблему безработицы и обнищания населения. Более того, эта мера не является инструментом развития.

Один из примеров помощи правительства производителям финансовая помощь крестьянам, выращивающим сахарный тростник, как важную экспортную культуру. Небывалая засуха 2020 г. привела к падению урожая сахарного тростника. Было произведено около 74,89 млн тонн, что меньше запланированных 100 млн тонн. Правительство одобрило финансовую помощь 300 тысячам производителей сахарного тростника на сумму 10 млрд бат, разделенных на два транша. Из них 6,5 млрд бат для тех производителей, которые собрали урожай и поставили его на фабрики. Второй транш 3,5 млрд бат для тех производителей, которые не жгли свои поля сахарного тростника во время сбора урожая и, таким образом, внесли вклад в снижение загрязнения воздуха 9 . В стране существуют планы развития сельского хозяйства с использованием новых технологий, в том числе, компьютерных, но давать оценку этим планам пока рано.

Значительно пострадал производственный сектор. Во время кризиса, за первую половину 2020 г. были закрыты 404 предприятия, работу потеряли 16 тыс. 680 рабочих ${ }^{10}$. Большая часть предприятий принадлежит к среднему и малому бизнесу. Правда, чиновники Департамента не считают эту цифру критической по сравнению с 666 фабриками, закрытыми в 2019 г. Одновременно, по их данным, за этот период зарегистрировано 1702 новые фабрики, что составляет рост на 10,2\% по сравнению с прошлым годом. В деловых и правительственных кругах считают, что Таиланд продолжает оставаться привлекательным для иностранных инвесторов. В связи с этим, чиновники Департамента промышленности представили Министерству план из пяти крупных инвестиционных проектов на сумму 148 млрд бат, обсуждение которых следует перенести на конец года.

Туристический бизнес. Большой урон нанесен туристическому сектору экономики ${ }^{11}$. В 2019 г. страну посетили 39 млн туристов, однако, по прогнозу Банка Таиланда, в этом году в страну приедут всего 8 млн туристов ${ }^{12}$. В прошлом году отрасль заработала 60 млрд бат, что составило пятую часть дохода страны. С туризмом связана работа аэропортов, торговли, в том числе мелкой, организаторов экскурсий, гидов и экскурсоводов, водителей автомобильного 
транспорта. Десятки тысяч людей оказались без работы. В Таиланде оценили возможную сумму ущерба от вспышки коронавируса. По данным газеты Bangkok Post, эпидемия может лишить туристический сектор страны доходов на сумму 1,63 млрд долл., или 50 млрд бат ${ }^{13}$.По оценкам председателя Совета по туризму Таиланда Чайрата Траираттаничаратпхона, предполагаемые потери основаны на средних расходах на одного посещающего Таиланд китайского туриста, которые составляют примерно 50 тыс бат. (или 1630 долл.). Эпидемия вируса серьезнее всего затронет малые и средние туристические компании, поскольку у них меньше капитал, чем у крупных операторов. Совет возлагает надежды на правительство, которое попросили принять меры, чтобы помочь ослабить последствия распространения коронавируса на сферу туризма. Совет вместе с органами здравоохранения проводит работу с местными жителями и туристам, посещающими популярные туристические направления, включая Чиангмай, Пхукет, Краби, Паттайю и Самуи, рекомендует им носить защитные маски, чаще мыть руки и без необходимости не посещать людные общественные места. Чиновники правительства обсуждают ситуацию с представителями туристических агентств, авиакомпаний и отельного бизнеса.

Китайские туристы составляют $28 \%$ из 39,8 миллионов, посетивших страну в 2019 г. $^{14}$. В 2019 г. Таиланд посетило 10 млн китайских туристов, которые потратили 580 млрд бат или около $30 \%$ от всех средств, потраченных иностранными туристами ${ }^{15}$.В Таиланде ожидают октября, традиционного туристического пика для китайских туристов, когда Китай празднуют свой национальный праздник и имея праздничные каникулы, китайцы отправляются в туристические путешествия. Власти обсуждают возможность открытия страны для иностранных туристов без соблюдения карантинных мер и на определенных условиях: ситуация с вирусом в этих странах должна быть под контролем. Речь идет о том, чтобы достичь соглашения о туризме со странами Азии, находящимися на расстоянии 6 часов полета, и должно касаться бизнесменов или тех, кто прилетает в страну для медицинского туризма. Они должны будут представить сертификат о здоровье перед посадкой в самолет, летящий в Таиланд, пройти тест на COVID-19 ${ }^{16}$. Туризм постепенно начинает восстанавливаться. Австралия, Новая Зеландия начали переговоры о воздушном сообщении. Япония рассматривает возможность снять запрет на въезд для таиландских граждан. Каждый день меняется текущая обстановка, на которую власть старается опера- 
тивно воздействовать. Но одновременно правительство рассматривает перспективные планы по выходу из экономического кризиса. Что касается туристической отрасли, то в докладе Конференции $\mathrm{OOH} \mathrm{по} \mathrm{торговле} \mathrm{и} \mathrm{развитию} \mathrm{дается} \mathrm{прогноз} \mathrm{о} \mathrm{потере} \mathrm{туристиче-}$ ской отраслью Таиланда 47 млрд долл., об этом 2 июля сообщает газета Бангкок Пост. Очевидно, что требуются новые подходы для восстановления отрасли. Развитие туристического бизнеса рассматривается как одно из важнейших направлений преодоления падения роста экономики страны.

Правительство предлагает несколько стратегий. Во-первых, развитие внутреннего туризма и вовлечение в него граждан своей страны. Так, 30 июня были одобрены два финансовых пакета субсидий для поощрения местного туризма, которые будут действовать вПлоть до 31 октября на сумму 22,4 млрд бат ${ }^{17}$. Во-вторых, планируется увеличить доходность отрасли за счет снижения числа бюджетных туристов и переориентацию на состоятельных клиентов, готовых тратить больше средств. В-третьих, создать в стране хаб медицинского туризма. За последние годы Таиланд заслужил репутацию страны, имеющей развитую сеть современных медицинских учреждений и готовой предоставить квалифицированную медицинскую помощь мирового класса, заботливый уход и благоприятную атмосферу отдыха по сравнительно более низким ценам, чем в других странах, и уже превратился в медицинский и оздоровительный центр. Причем, Таиланд стал медицинским и оздоровительным центром не только для Азии, но и за ее пределами. По данным Таиландского национального бюро статистики, в 2017 г. страну с целью лечения и оздоровления посетило 3,3 млн туристов $^{18}$. Министерство здравоохранения провело исследование и выяснило, что наиболее востребованными услугами в этой отрасли являются хирургия, сложная ортопедия, экстракорпоральное оплодотворение, стоматологическая помощь. Министерство способствует развитию десяти областей медицинских и оздоровительных услуг на самом высоком, глобальном уровне, а именно: регенеративные и омолаживающие процедуры на основе современной науки; альтернативная медицина; кардиология, исследования и лечение опорно-двигательного аппарата, стоматология, экстракорпоральное оплодотворение, онкология, хирургия, офтальмология (катаракта) и прецизионная или персонализированная медицина (основанная на генетическом профиле каждого человека, предоставляет индивидуальную схему профилактики и лечения). По международ- 
ному индексу медицинского туризма Таиланд занимает 6 место из 41 по привлекательности для туристов. По качеству услуг - 18 место из 41. При этом в Таиланде используются научные достижения медицины, биотехнологии и компьютерных технологий. Таким образом, Таиланд вправе претендовать на превращение в центр медицинского туризма для всего мира. Это, в свою очередь, будет стимулировать совершенствование медицинских учреждений (клиник, госпиталей и т.д.), развитие инноваций, клинических исследований и фармацевтики на самых современных достижениях науки. Правительство рассматривает меры организационно-финансового поощрения для развития производства медицинской техники, оборудования медикаментов на территории специальной экономической зоны - Восточного экономического коридора.

Оценка деятельности правительства. Представители правительства считают, что государством приняты адекватные меры по финансовой поддержке населения и бизнеса в период коронавируca, а что касается мега-проектов, таких как строительство высокоскоростной железной дороги, которая соединит три крупнейших международных аэропорта страны Донмыанг, Суваннапхуми и Утапао, то, несмотря на пандемию, их реализация продолжается. Согласно опросам общественного мнения, население в целом удовлетворено деятельностью правительства Праюта Чан-оча по борьбе с коронавирусом. Этой точки зрения придерживается Калин Сарасин, председатель Таиландской торговой палаты и Совета по торговле Таиланда. (Речь идет только о сфере экономики. В политике продолжаются протесты против военного, по сути, правительства.) Несмотря на некоторое смятение, вызванное коронавирусом, правительству удалось уберечь страну от худшего развития событий, чему поспособствовали введение чрезвычайного положения в конце марта и комендантского часа. Последующее закрытие школ, ресторанов, других общественных мест приостановило расползание заболевания. После пика количества вновь инфицированных 22 марта (188 случаев) наблюдалось постепенное их снижение. Правительство оказало помощь тем, кто потерял работу и более уязвимым группам населения, а также - предпринимателям. Однако, по мнению экспертов, для преодоления экономического кризиса в стране, осложненного мировым спадом, требуется масштабный план восстановления и развития. Ряд экономистов, оценивая экономическую деятельность правительства в целом, как, например, Ат Питсанванит, директор Центра изучения международной торговли при Уни- 
верситета Торговой палаты Таиланда, отмечают, что они неудовлетворительны, поскольку не решены проблемы падения цен на сельскохозяйственные продукты и снижающаяся конкурентоспособность таиландских товаров в международной торговле ${ }^{19}$.

Одновременно ведется работа над масштабным планом вывода экономики из кризиса на путь устойчивого развития. Для этого требуется разработать новую стратегию, нацеленную на перезапуск пострадавших отраслей, борьбу с безработицей, поиск новых направлений развития, способных быстро и эффективно восстановить экономику и темпы ее роста. В настоящее время обсуждается и частично реализуется несколько направлений, которые должны стимулировать развитие экономики страны. Задача осложняется тем, что многие отрасли страны ориентированы на экспорт или, как туризм - на приток иностранцев. Это делает экономику страны уязвимой и зависимой.

Правительство считает, что стимулировать экономику страны поможет масштабный транспортный и экономический проект развитие Восточного экономического коридора на побережье Сиамского залива, на который планируется потратить 1,7 трлн бат. Частью этого проекта является превращение ныне действующего аэропорта Утапао в город-аэропорт, на который планируется потратить 290 млрд бат. (9,4 млрд долл.). Это должно способствовать развитию промышленности и туризма в провинции Районг, где расположены многочисленные предприятия нефтехимии и автомобилестроения. Сюда же пребывают тысячи туристов из Китая и России на отдых в курортном городе Паттая. После реконструкции аэропорт Утапао сможет принимать 60 млн пассажиров в год и 3 млн тонн грузов. Там же планируется создание зоны свободной торговли, центра ремонта авиационной техники, размещение офисов логистических компаний и интернет торговли. Строительство нового терминала ведется консорциумом с участием BTS Group Holdings Pcl, Bangkok Airways Pcl и Sino-Thai Engineering \& Construction Pcl. Управление аэропортом будет вести японская Narita International Airport Corp. Считается, что город-аэропорт к концу 2021 г. даст стране прибавку в 1,5\% роста экономики ${ }^{20}$.

Международное сотрудничество. Таиланд вместе с другими странами АСЕАН стремится к сотрудничеству в борьбе с коронавирусом как внутри Ассоциации, так и другими странами, например, с Китаем и Россией. Представители Таиланда предложили создать единый фонд АСЕАН на случай чрезвычайных ситуаций. В 
контексте международного сотрудничества можно упомянуть совещание специалистов здравоохранения АСЕАН и Китая в Джакарте 31 марта; 36 саммит АСЕАН в Ханое 26 июня, который проходил в режиме телеконференции под председательством премьерминистра Вьетнама Нгуен Суан Фука ${ }^{21}$; онлайн-совещание в Джакарте по инициативе Индонезийской стороны министров иностранных дел стран АCEAH и России по COVID-19, где обсуждалось сотрудничество с нашей страной по трем направлениям: разработка и закупка вакцин и лекарств; сотрудничество в области здравоохранения с помощью различных механизмов, существующих в АСЕАН; сотрудничество в контексте восстановления экономики. Индонезия также призвала Россию стать ведущим игроком в улучшении управления общественного здравоохранения в регионе, включая предотвращение будущих кризисов.

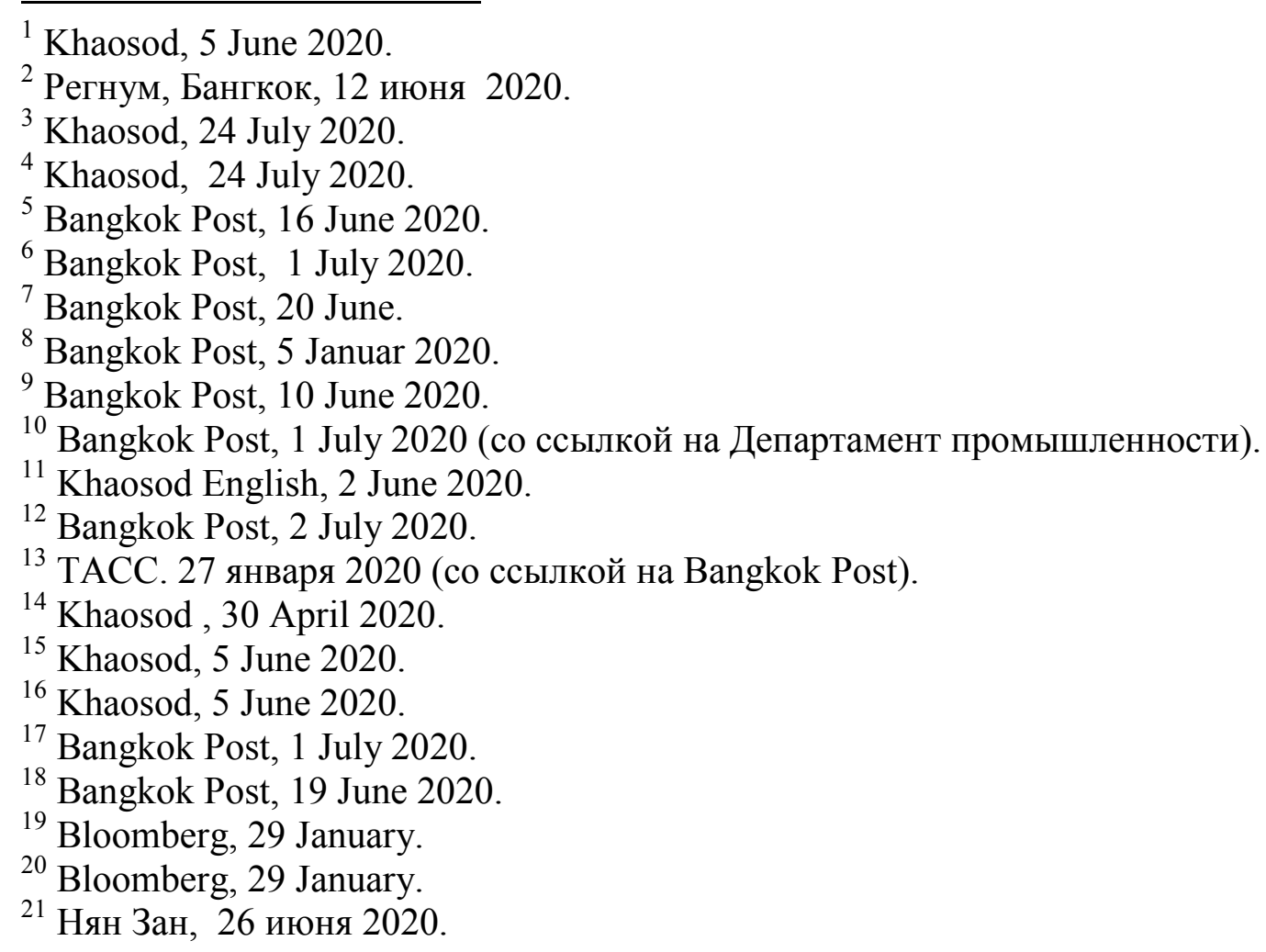

Статья поступила в редакцию 06.06.2020, принята к публикации 18.06.2020. 